\title{
Water Framework Directive (An "Open up" Tool for Public Participation in Water Policy)
}

\section{Dr. Polytimi M. Farmaki}

Legal Advisor ANKO SA, PhD, Department of Accounting and Finance, Western Macedonia University of Applied Sciences, Kozani, Greece

Email: pmfarmaki@gmail.com

\begin{abstract}
:
The new EU Water Framework Directive (WFD) 2000/60 prescribes an adaptive water governance system and has been the European Union's most comprehensive tool for the management and protection of water resources. This article analyses how WFD encourages the active involvement of "all interested parties" and represents how public participation has a key role in successful implementation. The aim of this paper is to understand the functioning and effectiveness of the new model introduced to address the lack of implementation of EU environmental rules, as WFD since its introduction in 2000, requires member states to design and implement river basin management plans via participatory processes. Moreover, we have identified that Common Implementation Strategy of WFD was designed as a tool for public participation and stakeholder involvement to river basin management planning and how participatory approaches are implemented as the new "governance" within the EU in the field of environmental policy.
\end{abstract}

Keyword: Water Framework Directive; integrated water resources management; river basin planning; public participation; water governance; 


\section{Introduction}

The most important factor influencing water management and protection policy over the two last decades, has been the change that has taken place within the EU with the adoption of European new governance forms in the context of EU environmental policy. The decision to drastically reform water policy was not taken suddenly and unjustifiably but was a response to political, economic and social developments at European level, and the result of pressure from many different parameters such as (Kallis, G. and Nijkamp, P. 2000):

- Reports concerning deteriorating water status quality in Europe. Two years after the implementation of WFD the key facts of water situation in Europe are: a) 20\% of all surface waters in the EU is threatened by pollution and river water quality does not improve overall, with the exception of some rivers with serious pollution problems b) Groundwater provides $65 \%$ of all drinking water in Europe, with high concentrations of nitrogenous substances, insecticides, hydrocarbons and heavy metals c) $60 \%$ of European cities are overexploiting their groundwater resources and $50 \%$ of wetlands are at risk due to overexploitation of groundwater resources. Obviously, total water pumping has decreased significantly since 1980, mainly due to the removal of heavy industry and reorientation d) he area of land irrigated has highly risen (European Commission, 2002)

- The high cost of implementing the data and standards set by the directives by the Member States

- Reactions against the EU centralized approach in relation to economic data and the nonadaptability to the local conditions characterizing each Member State

- The gaps and contradictions between the provisions in many and different directives

- The finding that water resources quality and quantity are both two characteristics that could not be addressed separately

\section{Public Participation in WFD: Theoretical Background}

One of the more discussed and analyzed topics of WFD is public participation and stakeholder involvement. The WFD 2000/60/EC refers in its article 14 «Public information and consultation» that:

"...1. Member States shall encourage the active involvement of all interested parties in the implementation of this Directive, in particular in the production, review and updating of the river 
basin management plans. Member States shall ensure that, for each river basin district, they publish and make available for comments to the public, including users:

Article 14 calls on the Member States to encourage the active involvement of all stakeholders in the individual stages of implementation of the Directive, as well as in the establishment of river basin management programs. "Public participation" is not only provided for in Article 14 of the Directive, but also in individual provisions in the Preamble, in other Articles and in the Annexes.

The following guidelines are set out in the Preamble to the Directive, points 14 and 46: 14 . «...The success of this Directive relies on close cooperation and coherent action at Community, Member State and local level as well as on information, consultation and involvement of the public, including users...» 46 «To ensure the participation of the general public including users of water in the establishment and updating of river basin management plans, it is necessary to provide proper information of planned measures and to report on progress with their implementation with a view to the involvement of the general public before final decisions on the necessary measures are adopted...»

Finally, Annex VII sets out the content of river basin management plans as follows: «...A. River basin management plans shall cover the following elements:

9. a summary of the public information and consultation measures taken, their results and the changes to the plan made as a consequence;

11. the contact

points and procedures for obtaining the background documentation and information referred to in Article 14(1), and in particular details of the control measures adopted in accordance with Article 11(3)(g) and 11(3)(i) and of the actual monitoring data gathered in accordance with Article 8 and Annex $V \ldots »$...

The question, however, is what is the meaning and definition of terms "participation" and "public" and to which groups of people does it refer, because Article 2 of the Directive, although it contains a multitude of definitions, does not define the specific concepts.

However, after the adoption of Directive 2000/60, several texts have been drafted by the Commission Water Directorate and the environmental organization WWF, which have provided 
guidelines on how to implement the provision of Article 14 and the implementation of public participation.

These documents, in conjunction with the common implementation strategy of the directive, which was drawn up jointly by the Member States with Norway and the Commission, contain a number of elements for defining the concept of "public participation".

Participation" is a concept that is interpreted in many different ways under the Directive, but it is generally accepted that the process by which anyone with a direct interest in a decision is ensured is involved in the adoption of that decision. The types and manner of "involvement" of stakeholders varies depending on how passive or active their role is in the decision-making process. The following table is a categorization of the types of participation and their characteristics (Harrison, A., Schmidt, G., Avis, C., Hauser, R. 2001):

\section{Table 1: Types of Participation}

\begin{tabular}{|c||c|}
\hline \multicolumn{1}{|c|}{ PARTICIPATION } & CHARACTERISTICS \\
\hline INFORMATION & $\begin{array}{c}\text { People get involved through information about what } \\
\text { has already been decided or has already happened. }\end{array}$ \\
\hline CONSULTATION & $\begin{array}{c}\text { People participate through consultation or with } \\
\text { questions asked }\end{array}$ \\
\hline IMPLEMENTATION & $\begin{array}{c}\text { People participate to achieve the goals set by those } \\
\text { who started the process }\end{array}$ \\
\hline CO-DECISION & $\begin{array}{c}\text { People are involved together in the analysis of events } \\
\text { and the development of action plans }\end{array}$ \\
\hline \begin{tabular}{|l} 
INDIVIDUAL \\
DECISION
\end{tabular} & $\begin{array}{c}\text { People participate by taking independent initiatives to } \\
\text { change plans and policies }\end{array}$ \\
\hline
\end{tabular}

Public (or "general public") definition is given in SEIA Directive (2001/42/EC) and Aarhus convention art. 2(4)) as "One or more natural or legal persons, and, in accordance with national legislation or practice, their associations, organizations or groups" Interested party (or "stakeholder") is considered as any person,

Group or organization with an interest or "stake" in an issue, either because they will be directly affected or because they may have some influence on its outcome. "Interested party" also includes 
members of the public who are not yet aware that they will be affected (in practice most individual citizens and many small NGOs and companies).

There is a wealth of definitions in the literature about public participation as it is a multidimensional concept which refers to: (1) who participates, participation of interest group representatives, stakeholders and the public; (2) how participants exchange information, from simple one-way provision of information, to intensive dialogue and deliberation in public meetings; and (3) power to influence the final decision and policy implemented (Fung). Participation is defined as the involvement of non-state actors in collective decision- making processes and in social sciences it is closely connected to public involvement. The involvement means that participation of the public starts from the agenda setting stage and goes all along till the final implementation stage (Newig, J., Pahl-Wostl, C., \& Sigel, K. 2005).

Bibliographic findings of studies conducted present particular interest in the context of Directive 2000/60 on water resources management are the various forms of public participation (information, consultation, discussion, co- designing, co- decision making, decision making). In his study Johnsson (2005) by investigating public participation in Sweden, through committees comprised of groups and stakeholders came to the conclusion that if something affected the environment people were more likely to react. More interesting was Mostert et al. (2007) study which based on the case studies of $10 \mathrm{EU}$ countries arrived to the conclusion that the role of stakeholders was limited as countries didn't want to move from the traditional governance style of policy and implementation to a participatory process. But even in countries with a corporatism tradition such as Sweden, the results of the study of Jager, N.,et al (2016) showed that public participation in WFD was limited. In another study Ozerol and Newing (2008) tried to develop criteria in order to evaluate the results of public participation in water resources management. Their man finding was that public participation should be carried out by local authorities as there were deficits in communication, information, knowledge, involvement and financing of stakeholders. All these studies were based on the new modes of environmental governance.

A study of the individual provisions (article 14 and Annex VII) makes it clear that the Framework Directive includes three forms of "public participation" (Barreira, A. and Kallis, G. 2003):

- Active participation in all dimensions of the directive implementation and especially in the design process. Active participation means, 
on the basis of the terms and conditions of the Directive: (a) participation in the designation and analysis of the catchment area through the identification of basins (Article 3), the analysis by economic and man-made factors (Article 5), the definition of protected areas; (Article 6), (b) participation in the assessment of the status of river basins, in relation to the requirements and data set by the Directive; (c) design and implementation of the program of measures; and (d) implementation of river basin plans in the case of international basin coordination of stakeholders.

- Consultation enabling the acquisition of knowledge from the comments, experiences and views of the stakeholders. Public consultation is essential for the adoption of river basin management plans. The consultation process is carried out through the obligation of the Member States to make available to the public a timetable and work program, on the management plan of each basin and on the exchange of views and positions between those involved through an oral procedure and written comments.

- Access to information that formed the basis for decision making. Access to information means adequate provision of information at all stages of the implementation of the Directive and access at the request of the public to documents and information used by States to formulate the river basin management plan.

Table 2: Public Participation

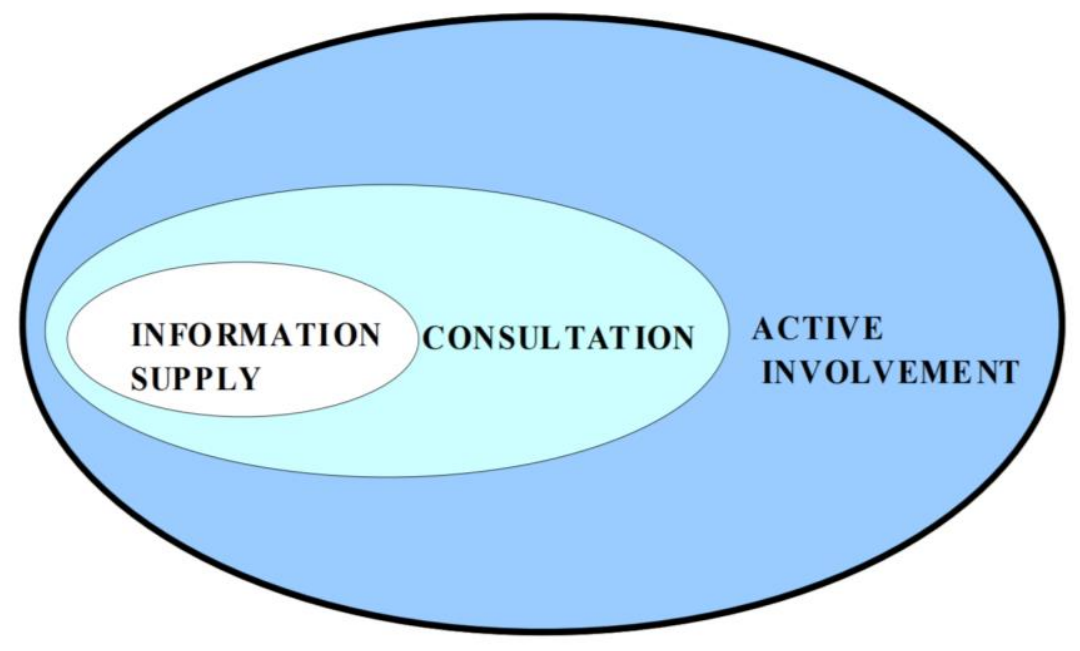


Source: Water Directors, Guidance on public participation in relation to the Water Framework Directive, Active involvement, Consultation, and Public access to information, Final Draft 1.3 (24/10/2002), endorsed during the informal meeting under the Danish Presidency in Copenhagen.

Among those three forms of participation, two information supply and consultation should be provided by the Member States, while the third active involvement should be encouraged. Furthermore, based on the obligations arising from this article, Member States should consult the public and water users on: a) the timetable and action plan for the preparation of management plans, b) the review of important issues and c) the draft management plans (Andreadakis, A. 2002).

Consultation is Lowest level of public participation if we consider information supply as being the foundation. The government makes documents available for written comments, organizes a public hearing or actively seeks the comments and opinions of the public through for instance surveys and interviews. "Consultation" in art. 14 of the Directive refers to written consultations only. Preamble 14 and 46 and Annex VII refer to consultation in general. On the other hand active involvement is a higher level of participation than consultation.

Active involvement implies that stakeholders are invited to contribute actively to the planning process by discussing issues and contributing to their solution.

The information-updating and the consultation with the public will take place after the creation of a preliminary plan for the management of the river basin, but the interested parties will have direct access to the supporting documents and information, which were used for the elaboration of the plan. This point of the directive has been heavily criticized, because, while emphasizing the need for transparency and participation at the critical stage of the proposed policy-making process, participation will be belated and highly limited.

Within the EU, significant efforts have been made so as to establish a legal framework on the right of citizens to get informed about environmental issues. The aim of the Community was the involvement of citizens and the achievement of "shared responsibility", as a means of active "public" participation in the processes of production and implementation of environmental policy. The Directive 90/313 has been the first step in this effort.

The revision of Directive 90/313/EC was another measure to address implementation problems. 
The particular directive provided that the public could have access to environmental information in order to be informed about the environmental impact of industrial activities and government decisions. The Directive also required Member States to publish information on the general state of the environment. However, the substantial experience gained from the implementation of this Directive mainly concerned access difficulties, which were as follows:

- the identification of the information that could be disclosed and the competent authorities for the provision of this information

- the exceptions to the obligation to access information and the obligation to state reasons for refusal

- the time limits and related charges for providing the information

At the end of 1999, the Commission's Directorate-General for the Environment presented a working document on the revision of the dual-purpose directive, addressing all the abovementioned difficulties and aligning Community legislation with the provisions of the Aarhus Convention.

Proper and complete information of the citizens and their access to as much information as possible is a key element for the effectiveness of government policies. Equally important is public access to public documents (Lymouris, N.P. 2001),

in order to avoid mistakes and abuse of power by civil servants and institutions in general. On 26 January 2000, the Commission adopted a proposal for a Council and European Parliament regulation on public access to European Parliament, Council and Commission documents. This proposal aims to implement Article 255 of the EC Treaty, which recognizes European citizens and residents of the Union the right of access to European Parliament, Council and Commission documents. Regulation 1049/2001, L145 / 43 of 31 May 2001. Access to information and updating are the key tools for strengthening citizens' rights and their access to the process of production and implementation of environmental law.

Providing information to citizens is the basis for achieving their involvement in environmental issues and the success of the institutions' initiatives in the field of environmental policy. It is necessary for the citizens to know exactly what, for what reason and by whom each initiative is going to be taken, since only with clear answers to these questions might the interest of the "public" for the environment be refined. 
Obviously, the provision of information to citizens by local authorities requires some financial costs, which, however, is minimal compared to the costs required in the event of a reaction of the "public" to the implementation of an initiative (Filho, W.L. 1999).

OECD in a survey conducted on the possibility of citizen involvement in the legal process gave a definition for informing citizens. According to this definition, information is a one-way relationship in which governments produce and deliver information to citizens. The information covers both "passive" access to information at the request of stakeholders and "active" measures by the government to provide information to citizens (OECD 2001) .

In the field of water resources, informing the public and providing information to citizens by specialized scientists could significantly contribute to the awareness of the value of water and the problems that exist due to over-consumption and pollution. According to research conducted at the Institute of Geology and Paleontology at Darmstadt University of Technology, one of the main reasons for the increase in environmental pollution and misuse of water resources is the lack of interest and education of citizens on environmental issues. According to the professor who conducted the research, environmental education should not be aimed only at specific population groups such as pupils or students, nor exclusively in industrialized countries, but should cover the entire population, worldwide. In addition to ordinary citizens, a specific goal of environmental education should be the continuous training and education of specialists and engineers involved in water resources management.

The conclusions of the research advocated as a solution to address environmental problems related to water, the cooperation of special scientists and institutions and the awakening and education of citizens with the aim of their participation in the design and implementation of various policies in the field of water. The results of this research were presented during the International Symposium, organized by the European Thematic Network of Education and Training in collaboration with the International Hydrological Program of UNESCO, entitled: "The learning society and the water- environment" (Bundschuch, J. 2000).

\section{Common Implementation Strategy as a tool for public participation}

After the adoption of WFD, Norway and the European Commission formulated a Strategy for the Joint Implementation of the Directive under the Swedish Presidency (Common Implementation Strategy). 
The reasons, which led the Member States to create a common strategy for implementing Directive 2000/60 / EC according to the Strategic document: "Common Strategy on the Implementation of the Water Framework Directive" were:

- The long and demanding timetable for the implementation of the individual provisions of the Directive

- The complexity of the individual provisions

- The diversity of possible solutions to technical, scientific and practical problems

- The large number of substantive arrangements contained in the annexes

- Strict limitation of human resources and financial resources available for the directive implementation

The adoption of the Joint Implementation Strategy was preceded by an informal meeting of EU Water Directors with the Norwegian Water Directorate, held under the French Presidency of the Council, in Paris on 23-24 October 2000, setting out the guidelines and identifying the key elements for implementing the :

- The exchange of information between Member States and the European Commission

- The participation and information of the "public" on the key points of the directive and the implementation process

- Achieving coherence between the implementation of the Other Sectoral Policies Directive and the other Water Directives

- The active involvement of stakeholders, NGOs and civil society in the implementation of the directive

- The establishment of working groups and the implementation of formal guidance documents for implementation

- The establishment of infrastructure structures in the Member States for the effective implementation of the Directive

- The design of integrated river basin management plans

- The development of cooperation with the candidate countries and the study of the possibility of their involvement in the implementation of the Directive (in particular for the management of the international transboundary river basins of the Community)

The Common Implementation Strategy document identified many advantages of Public Participation in water policy making, such as public awareness, use of knowledge of different 
stakeholders, reduction of delays in implementation and effective interaction between public government and experts. The provision for the active participation of the "public", NGOs and civil society was, after all, the key tool for achieving all the long-term and intermediate objectives in the implementation process of the Directive and was in line with the provision of the $5^{\text {th }}$ Environment Action Program. For division of responsibilities, "shared responsibility", at different levels of government (European, national, regional and local).

However, although the strategic document for the implementation of Directive 2000/60 / EC provided for the participation of all stakeholders, this participation would take the form of informal meetings and consultations and it left considerable room for interpretation and produced nonlegally binding documents (Brouwer 2013). Public participation was one of the main challenges in WFD, but what is the real meaning of this participation in the Water Framework Directive and how it reflects the shift «from government to governance»? What difficulties are found in the transition from the legal framework to the practical implementation of the Water resources management in the River Basin District 09 in Western Macedonia, Greece? This study aims to answer the above questions by investigating the theoretical background of public participation in the WFD and by analyzing the level of public participation in River basin management plan in the River Basin District 09 in Western Macedonia, Greece. Finally, some conclusions are posed in order to make policy recommendations.

The main objective of this new strategy was to address the weaknesses of the "command and control" regulatory model in the implementation of Community environmental law,

through the involvement of "stakeholders" in shaping the implementation process of Community directives. Nevertheless, the involvement of the "public" is perhaps the most appropriate way to address the implementation gap.

The principles on which the Strategy for the Implementation of the Directive is based are the principles of transparency, partnership and "shared responsibility". These principles, combined with the key elements that characterize the way the directive is implemented, compose the concept of the new form of European governance in the context of EU environmental policy for greater flexibility in the means of implementing EU policies, as provided for in the White Paper on Commission Governance.

\section{Discussion}


The diffusion of decision-making responsibilities at different levels and the strengthening of decentralization and local government are the main issues analyzed in the present study (Hooghe L. Marks G. 2001). This "new" form of organization of the administrative mechanism of the modern western state is expressed in the multilevel governance developed within the EU, in order to describe the complex interactions between all actors (EU institutions, governments, regional and local government bodies, NGOs, business interests, organizations) involved in EU procedures (DeBardeleben J. and Hurrelmann 2007) .

Scholars support two views on the role of the EU unification process. in shaping multilevel governance. A. Moravcsik supported among others, that the unification process strengthened the role of the state at the expense of local and decentralized administration and the participation of states in the EU led to an over-concentration of power in the administrative and governmental elites and the diffusion of power to a limited number of levels (Type I of multi-level governance). The opposite view holds that the EU imposed on the nation-states its own structure of multilevel governance, strengthened the role of local government and organized interests, by diffusing responsibilities at various levels (Type II multilevel governance).[5]

The key features of the new "governance" within the EU in the field of environmental policy (COM (92) 23 final) and in particular, the management of water resources, as set out in Framework Directive 2000/60 are (Baker Susan, 2001, Kooiman J. 1993, Baker Susan 1997, Hix Simon 1998, Cini Michelle 2000):

$\rightarrow$ The integration and implementation of the principles of "cooperation" and "shared responsibility" in the formulation and application of Community environmental law

$\rightarrow$ Participation in the exercise of governance - outside the EU - social, political, and administrative factors and the downsizing of power, that is, the move of EU power - in some areas - to regional and local institutions and NGOs for a healthy European governance requires the cooperation of European, national, regional and local governments. These four stages are, each one separately, necessary and their presence is required throughout the decision-making process

$\rightarrow$ He non-hierarchical involvement of governmental and non-governmental actors (NGOs, economic operators, services) in both the production process and the application of Community law. 
$\rightarrow$ The use of new environmental policy tools, such as fiscal incentives, horizontal aids (information, research, and education), financial support mechanisms and voluntary agreements (EMAS, Eco-label, and ISO, aiming at rewarding environmental performance.)

$\rightarrow$ The integration of environmental policy into other sectoral policies. This means that environmental concerns should be included in other policies and that other General Directorates of the Commission should take their environmental impact into account when designing their programs and actions.

$\rightarrow$ The efficient operation of institutions, bodies, and the transparency of their work with the simultaneous access of the citizen.

\section{Conclusion}

After the implementation of WFD in the water sector, there has been a significant increase in the stakeholders involved in management and an increase in the role of both governmental and non-governmental actors. In addition, new management bodies were set up and the private sector invaded as a new factor in water management and supply. At the same time in the field of decisionmaking and establishment of water management law, significant changes took place with the integration of the principles of "cooperation" and "joint responsibility" and the non-hierarchical involvement of different levels and decision-making centers.

This paper shows that WFD is an important instrument for the participation of interested parties and the public, whereas the competent authority has only the responsibility to implement the management plan. The new water policy implemented trough the WFD created a new system of bodies at local, national, European and international level that collectively made decisions and exercised the management of water resources (Kaika, M. 2003).

\section{References}

1. Andreadakis, A. (2002). The importance of coordinated action for the implementation of the Water Framework Directive 2000/60" Technical Chamber of Greece, 2206, 39-111

2. Baker Susan (1997). The evolution of European Union environmental policy, From growth to sustainable development, 101

3. Baker Susan (2001). Environmental governance in the EU in Thomson Grahame (ed.) Governing the European Economy, London, Sage, 205 
4. Barreira, A. and Kallis, G. (2003). The EU Water Framework Directive and public participation in transboundary river basin management in Timmerman J. Langaas S (eds) Environmental Information in European Transboundary Water Management, IWA publishing, 92-107

5. Bundschuch, J. (2000). The sustainability principle in water resources management requires education and training as missing link between problems and solutions in Van der Beken, A., Mihailescu, M., Hubert, P. and Bogardi, J. The learning society and the water- environment, Official Publications of the European Communities, Belgium, 79-85

6. Cini Michelle (2000). Administrative Culture in the European Commission: The Cases of Competition and Environment" in Nugent Neil (ed.) At the heart of the Union, Studies of the European Commission, Second Edition, Macmillan Press Ltd, 81- 82

7. COM (92) 23 final Volume II Towards Sustainability: A European Community Programme of Policy and Action in relation to the Environment and Sustainable Development

8. DeBardeleben J. and Hurrelmann (2007). Democratic Dilemmas of Multilevel Governance Legitimacy, Representation and Accountability in the European Union, Palgrave Macmillan, 2-5

9. Directive $90 / 313 /$ EEC EE L $158 / 56$ of $23^{\text {rd }} / 06 / 90$

10. European Commission, (2002). The Water Framework Directive. Tap into it! Office for Public Publications of the European Communities, Luxembourg, 2

11. Filho, W.L. (1999). Getting people involved" at Buckingham-Hatfield, S. and Percy, S. (eds) Constructing Local Environmental Agendas. People, places and participation, Routledge, London and New York, 36

12. Harrison, A., Schmidt, G., Avis, C., Hauser, R. (2001). WWF's preliminary comments on Public Participation in the context of the Water Framework Directive and Integrated River Basin Management

13. Hix Simon (1998). The study of the European Union II: the 'new governance' agenda and its rival, Journal of European Public Policy, 5, 38- 65

14. Hooghe L. Marks G. (2001). Types of Multi-Level Governance, European Integration online Papers (EIoP), 5 (11)

15. Jager, N., Challies, E., Kochskamper, E., Newig, J., Benson, D., Blackstock, K., Collins, K., Ernst, A., Evers, M., Feichtinger, J., Fritsch, O., Gooch, G., Grund, W., Hedelin, B., HernándezMora, N., Hüesker, F., Huitema, D., Irvine, K., Klinke, A., ... von Korff, Y. (2016). 
Transforming European Water Governance? EU Water Framework Directive implementation in 13 member states. Water, 8(4), 156. https://doi.org/10.3390/w8040156

16. Jonsson A. (2005). Public participation in water resources management: stakeholder voices on degree, scale, potential, and methods in future water management. Ambio. 34(7) 495-500..

17. Kaika, M. (2003). The Water Framework Directive: a new directive for a changing social, political and economic European framework, European Planning Studies, 11(3), 303-320

18. Kallis, G. and Nijkamp, P. (2000). Evolution of EU Water Policy: a critical assessment and hopeful perspective. Journal of Environmental Law and Policy, 3, 301-335

19. Kooiman J. (1993). Governance and governability: using complexity, dynamics and diversity in Kooiman J. (ed.) Modern Governance: New Government- Society Interactions, London, Sage, 2

20. Lymouris, N.P. (2001). Citizens' access to Community documents and the new regulation 1049/2001, Department of International, European and Area Studies, Panteion University

21. Mostert, E., Pahl-Wostl, C., Rees, Y., Searle, B., Tàbara, D., \& Tippett, J. (2007). Social learning in European river-basin management: barriers and fostering mecha-nisms from 10 river basins. Ecology and society, 12(1), 19

22. Newig, J., Pahl-Wostl, C., \& Sigel, K. (2005). The Role of Public Participation in Managing Uncertainty in the Implementation of the Water Framework Directive. European Environment, 15(6), 333-343.

23. OECD (2001) Engaging Citizens in Policy-making: Information, Consultation and Public Participation, Puma Policy Brief No 10. p. 2

24. Ozerol, Gül \& Newig, Jens. (2008). Evaluating the Success of Public Participation in Water Resources Management - Five Key Constituents. Water Policy. 10. 639-655. 10.2166/wp.2008.001.

25. Strategic document: "Common Strategy on the Implementation of the Water Framework Directive"

Copyright (C) 2021 Dr. Polytimi M. Farmaki, AJRSP. This is an open-access article distributed under the terms of the Creative Commons Attribution License (CC BY NC) Doi: doi.org/10.52132/Ajrsp.e.2021.301 